IRA-International Journal of Education \& Multidisciplinary Studies

ISSN 2455-2526; Vol.04, Issue 01 (2016)

Institute of Research Advances

http://research-advances.org/index.php/IJEMS

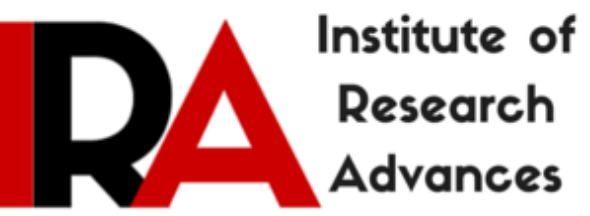

\title{
Learners' code-switching in English as a Second Language (ESL) lessons: perspectives of four secondary school teachers in Zimbabwe
}

Rugare Mareva

Great Zimbabwe University

Department of Curriculum Studies

P.O. Box 1235, Masvingo, Zimbabwe.

DOI: http://dx.doi.org/10.21013/jems.v4.n1.p10

\section{How to cite this paper:}

Mareva, R. (2016). Learners' code-switching in English as a Second Language (ESL) lessons: perspectives of four secondary school teachers in Zimbabwe. IRA International Journal of Education and Multidisciplinary Studies (ISSN 2455-2526), 4(1). doi:http://dx.doi.org/10.21013/jems.v4.n1.p10

(C) Institute of Research Advances

(c)) EY-NC

This works is licensed under a Creative Commons Attribution-Non Commercial 4.0 International License subject to proper citation to the publication source of the work.

Disclaimer: The scholarly papers as reviewed and published by the Institute of Research Advances (IRA) are the views and opinions of their respective authors and are not the views or opinions of the IRA. The IRA disclaims of any harm or loss caused due to the published content to any party. 


ABSTRACT
The study investigated the perceptions of secondary school teachers of English on code-switching by
learners in the learning of English. The qualitative inquiry focused on one rural day, and one urban
boarding school. The study employed interviews with four teachers from the two schools. Results
show that from the perspective of the teachers, their ESL learners code-switched from English to the
learners' L1 as a learning tool, mainly to foster understanding among learners and between the
learners and their teachers, and for other communicative and social functions. The teachers
expressed an appreciation of their learners' code-switching but there were also negative sentiments.
The study recommends that language policy planners revisit the English-only policy in schools and
consider adopting the endo-normative rather than the exo-normative model of English for the
education system. The study also recommends that the responsible Ministry should hold workshops to
sensitise teachers on how code-switching may be tolerated and exploited as a language learning tool.
Furthermore, the study recommends that ESL teachers be guided by the Postmethod pedagogy, a
sense of plausibility as well as the notion of relativism in their decisions on whether or not to allow
their learners to code-switch. In addition, the inquiry recommends that the Zimbabwe Schools
Examinations Council be sensitive to aspects of the local variety of English rather than set exo-
normative models. Finally, the study recommends that further research be done on code-switching in
school types which were not included in the sample for the present study.

Key Words: Code-switching, English as a Second Language, Target Language Approaches, Methods

\subsection{Background: The Linguistic Situation in Zimbabwe}

Located in Southern Africa, Zimbabwe, a former British colony, has a population of about 13 million according to the latest (2013) national census results. The linguistic situation in the country is that Zimbabwe is a multilingual country where there are 16 spoken languages (Hachipola, 1998). Of these, until the Constitution of Zimbabwe Amendment (No. 20) Act of 2013, English has been the official language while Shona and Ndebele have been national languages spoken by $70 \%$ and $15 \%$ of the population, respectively (Peresuh and Masuku, 2002). The others have been regarded as minority languages and these include Shangani, Venda, Kalanga, Nambya, Tonga, Chichewa, Sotho, Chikunda, Sena, Barwe, Hwesa, and Tshwawo (Chimhundu, 1997).

However, the Constitution of Zimbabwe Amendment (No. 20) (2013) raised the status of Shona, Ndebele, Chewa, Chibarwe, English, Kalanga, Koisan, Nambya, Ndau, Ndebele, Shangani, Shona, sign language, Sotho, Tonga, Tswana, Venda and Xhosa, to official languages of Zimbabwe.

Nevertheless, the place of English in Zimbabwe is that, like in many other former British colonies, the language continues to enjoy a higher social status than any of the indigenous languages since, for many years, it has been the only official language (Kadenge and Mabugu, 2009), yet English is the home language of less than $1 \%$ of the population (Peresuh and Masuku, 2002). English is the main language of international and intranational business, government, legislation religion, advertisements, political manifestos, and other important documents (Mabugu, 2009). English 'has remained the language of instruction in the private and public schools. It remains the language of the office. Furthermore, the ' $\mathrm{O}$ ' level school-leaving certificate cannot be complete unless one passes... English of course' (Mavhunga, 2006:447-448). English is, thus, perceived to be an economic gatekeeper (Nyawaranda, 2000).

Zimbabwe's national language policy on education as contained in the Education Act of 1987 (as amended in 1990) and as quoted in Nziramasanga (1999) stipulates that Shona, Ndebele and English, shall be taught in all primary schools from the first grade as follows with Shona and Ndebele being taught in all areas where they are the mother tongues of the majority of the residents. Also, prior to the fourth grade, Shona, Ndebele or English may be used as a medium of instruction, depending upon 
which language is most commonly spoken and better understood by the pupils. From the fourth grade, English shall be the medium of instruction provided that Shona or Ndebele shall be taught as subjects. In areas where minority languages exist, the Minister may authorise the teaching of such languages in primary schools.

However, Amended Education Act of 2006 stipulates that indigenous languages may be used as media of instruction throughout the primary school level, while English becomes the sole medium of instruction from Form One of secondary education.

What is clear from the linguistic situation in Zimbabwe, thus, is that English exists side by side with a plethora of indigenous languages and therefore, code-switching from English to either of the local languages, or vice versa, is bound to occur.

\subsection{Statement of the Problem}

The problem that has motivated this study lies in Zimbabwe's language policy on instruction, and the controversy surrounding the role of the learners' L1 in L2 instruction. Zimbabwe's language policy on instruction stipulates that English be the sole language of instruction in the teaching of all subjects (including of course English itself) except in the teaching of local languages as subjects, from Form One (Nziramasanga, 1999). Yet there is apparently never-ending debate regarding the role of the L1 in L2 instruction and in teaching and learning in general. As Storch and Wigglesworth (2003:760) aptly put it, 'The use of learners' L1 is a controversial issue in L2 education.' El-dali (2010) also acknowledges the existence of controversy regarding the use or avoidance of the L1 in the L2 classroom. Sachiko (cited in Nyawaranda, 2000) also observes that there are differences in opinion among teachers on the role of the mother tongue in instruction and these opinions reflect the differences in the teachers' wider beliefs about the best way to learn a language.

\subsection{Significance of the Study}

Against the backdrop of Zimbabwe's language policy on instruction which stipulates that English be the sole medium of instruction from the secondary school level upwards (Zimbabwe Amended Education Act, 2006) and against the backdrop of the controversy surrounding the role of learners L1 in L2 instruction (Al-Nofaie, 2010; Kafes, 2011) this study is significant in that it sought to unearth the perceptions of secondary school teachers on their learners' use of code-switching in the teaching and learning of English in Zimbabwe.

\subsection{Objectives of the Study}

The study sought to:

(a) find out, from the perspective of selected teachers, if secondary school learners in Zimbabwe code-switch in ESL lessons and in what situations.

(b) establish the selected teachers' perceptions on their learners' use of code-switching in the teaching of ESL.

\subsection{Theoretical Framework and Literature Review}

\subsection{Bilingualism}

This study is rooted in Bilingualism. Code-switching is a manifestation of bilingualism.

Grosjean (1982:51) argues that 'Bilingualism is the regular use of two (or more) languages, and bilinguals are those people who need and use two (or more) languages in their everyday lives.' Similarly, Hamers and Blanc (2000) regard a person as bilingual if they have access to two linguistic codes. 


\subsubsection{Some Models of Bilingualism}

These include the Transitional Model, Subtractive Bilingualism, Additive Bilingualism, the Separate Underlying Proficiency (SUP) Model, the Common Underlying Proficiency (CUP) Model, the Thresholds Theory, and the Developmental Interdependence Hypothesis. The models show the relationship between a language learner's L1 and the language being learnt (L2).

In the Transitional Model, learners are temporarily allowed to keep their L1 before being shifted to the dominant (official) language. They will only be moved to the second language when they are thought to be adequately proficient in it (Cummins, cited in Baker, 2006). The aim is to increase the use of the dominant language (L2), while proportionately reducing the use of the L1 (Villarreal, cited in Baker, 2006).

The Subtractive Bilingualism model demotes the L1, resulting in the loss of cultural identity and reduced self-concept (Baker, 2006). Also, in subtractive bilingualism, 'the bilingual feels that the second language is the cause of some loss with respect to the first' (Malmkjaer, 1991:58). In the model, learners are moved away from the mother tongue as soon as possible. This may occur when the second language and culture are acquired so as to replace or demote the first language and culture (Ndamba, 2013).

Additive Bilingualism promotes the development of both the L1 and the L2 and encourages the users' flexibility in them (Baker, 2006). In additive bilingualism, the bilingual 'feels enriched socially and cognitively by an additional language' (Malmkjaer, 1991:58). The addition of a second language or culture is unlikely to replace or displace the L1 and its culture. Also, the L1 is not dispensed with as the language of instruction (Baker, 2006).

The Separate Underlying Proficiency (SUP) Model posits that two languages cannot exist together in a person's mind at the same level, and that the two languages operate separately without transfer. Furthermore, a second language takes second place to the first one, thereby diminishing its level of proficiency (Cummins, cited in Baker, 2006). In other words, according to Talebi (2014:215) the model postulates that proficiency in L1 would be separate from proficiency in L2.

The Common Underlying Proficiency (CUP) Model fundamentally differs from the SUP model in that it holds that there exists a state of equilibrium between the first and the second language. Thus, there appears to be adequate celebral living quarters for them both (Cummins, cited in Baker, 2006). Therefore, according to (Talebi, 2014) when the child learns one language, he or she acquires skills and metalinguistic knowledge that can be depended on when working in another language. Thus, CUP provides the basis for the development of both the L1 and the L2.

\subsection{Role of the Learners' $L 1$ in the $\mathrm{L} 2$ Classroom}

One of the issues that have taken centre stage in the field of bilingualism and language teaching is whether or not the learners L1 should be used in the classroom. Macaro (2014) refers to the 'virtual' position, in which case the teacher's belief is that the whole teaching and learning process should be in the target language, the 'maximal' position in which while the teacher may agree in principle that all teaching and learning should be in the target language, he or she concedes, though begrudgingly, that in reality some L1 will be used because of the learners' low target language proficiency. Then there is the 'optimal' position, in which the teacher sees the L1 as playing a beneficial role in the teaching and learning of the L2 but has to be aware of both the pros and cons of using the L1 in the classroom.

Al-Nofaie (2010) acknowledges that the use of the L1 when teaching the L2 has dominated L2 acquisition for decades and has been a controversial issue. This observation is shared by Kafes (2011:28) who states: 'The role and use of L1 in instructed second/foreign language classroom... has without any doubt been at the crux of a fair extent of controversy, debate and discussion.' Both AlNofaie (2010) and Kafes (2011) identify two schools of thought that have either advocated for, or 
rejected the use of the L1 in L2 teaching and learning. These are the Bilingual Approach and the Monolingual Approach, respectively.

While the Bilingual Approach accepts or encourages use of learners' L1 in L2 teaching and learning, in monolingual teaching 'the teaching itself, as well as the organisation of the work in the classroom, should take place in the target language, (Simensen, 2007:236). This was advocated by the Reform Movement in the advent of the Direct Method, in which 'teaching in the target language itself would establish direct associations or links between L2 items and the things, actions, and the states talked about' Simensen, 2002:26). Cook (2001) observes that over the last century, use of the L1 in L2 learning has largely been regarded as taboo and was therefore banned or minimised. Cook also states that proponents of the Monolingual Approach argue that, firstly, the learning of an L2 should be modelled on the learning of an L1, that is, through maximum exposure to the L2. Secondly, the advocates claim that successful learning involves the separation and distinction between the L1 and the L2. Thirdly, it is argued that students should be shown the importance of the L2 by its continual use. Furthermore, the rationale behind the Monolingual Approach is that the more students are exposed to the target language (TL), the more quickly they will learn it and as they learn and use it, they internalise it to begin to think in it. Also, the only way that learners will learn the TL is if they are forced to use it (Auerbach, cited in Sharma, 2006). In the words of Cook (2008:95), 'the purpose of language teaching in one sense is to provide optimal samples of language for the learner to profit from - the best 'input' to the process of language learning.'

Moreover, according to Macaro (2001:551), proponents of L2 exclusivity argue that 'teaching entirely through the TL makes the language real, allows learners to experience unpredictability, and develops the learners' own in-built language system.'

On the contrary, Miles (2004) argues for the use of the Bilingual Approach, condemning the Monolingual Approach on the grounds that, firstly, it is impractical, secondly, native teachers are not necessarily the best teachers, and thirdly, exposure (to TL) alone is not sufficient for learning. Also in support of the Bilingual Approach, Brown (2000:68) says the first language 'can be a facilitating factor not just an interfering factor.' Brown is here alluding to the issue of language transfer, which is defined by Odlin (1993:27) as 'the influence resulting from similarities and differences between the target language and any other language that has been previously (and perhaps imperfectly) acquired.' The facilitating factor (Brown, 2000) is what is referred to as positive transfer, or a situation where similarities between the L1 and the L2 can facilitate learning. Positive transfer is also defined by Nunan (2000) as the use of the rules that coincide in both the L1 and the L2 and the learners using the L1 rules to benefit from learning the L2. The interfering factor (Brown, 2000) refers to negative transfer, or the use of L1rules in the learning of an L2 although such rules do not exist in the L2 (Nunan, 2000). Dulay and Burt (cited in Maniam, 2010), refer to negative transfer as interference, which they define as automatic transfer, due to habit, of the surface structure of the L1 on the surface structure of the L2. In apparent reference to the notion of negative transfer, Sridhar (1994:802) states that second language learners' first languages are 'not viewed as resources; they are at best shadowy presences, which have only a nuisance value as sources of interference and as the incompetent learner's last resource for performing with competence.' The term interference, however, is now viewed as representing an out-dated and incorrect view of the influence of L1 influence on L2 learning, so transfer is regarded as a more preferable term. Jarvis and Pavlenko (2001:1) define transfer as 'the influence of a person's knowledge of one language on that person's knowledge or use of another language.'

Cook (2002) identifies the concept of multi-competence, which is defined as the compound state of the mind with two grammars. Cook views L2 users as being different from L1 users and encourages language teachers to celebrate this difference, and adds that L2 users can never become native speakers, so comparing them to native speakers would set a standard that is unattainable and undesirable. Cook (2012) also says multi-competence takes the goal of language teaching as the production of a successful L2 user, not an imitation native speaker, and adds that multi-competence does not see any virtue in making learners use the L2 only in the classroom since this denies the existence of the L1 in their minds. Thus, Cook (2001) argues for the maximisation of the L1, since 
multi-competence means that the L1 is always present in the users' minds, hence it would be artificial and sometimes inefficient to avoid its use.

In support of the use of the learners' L1 in the L2 classroom, Corder (1992:24) avers that.

Second language learners not only posses a language system which is potentially available as a factor in the acquisition of a second language, but equally importantly they already know something of what a language is for, what its communicative functions and potentials are.

In addition, the L1 is seen as playing a chiefly heuristic and facilitatory role, helping in discovery and creation (Corder, 1992).

For Harbord (1992), using the L1 in the L2 classroom is a humanistic approach which allows learners to express themselves, and also to be themselves. Rigidly eliminating or limiting the native language does not appear to guarantee better acquisition, nor does it foster the humanistic approach that recognises learners identities as native speakers of a valuable language that is as much a part of them as their names (Harbord, 1992:351).

Also in support of the learners' use of their L1 in the L2 classroom is Nguyen (2010) who observes that being tolerant of the learners' L1 encourages their participation.

Macaro (2001) also avers that excluding the L1 in L2 learning is impractical and may deprive learners of an important tool for language learning. Macaro (2005:68) also argues that the L1 is 'the language of thought for all but the most advanced L2 learners.' Deller and Rinvolucri (2002) see the L1 as being not only necessary but also effective. Choong (2006:2) gives some of the reasons for using the L1 in the classroom as 'to convey and check comprehension of grammatical forms and meanings, to give instructions, and to manage the class', and adds that 'These things may be difficult or impossible to do without resorting to the L1, and it saves time that might be squandered trying to conform to a strict rule of L1 prohibition.' Also, Atkinson (1987), Piasecka (1988), and Harbord (1992), give many and generally similar L1 use occasions in the L2 classroom which are viewed as strategies to facilitate communication and learning.

In terms of theories of second language acquisition, the Sociocultural Theory (Lightbown and Spada, 2006; Lantolf and Thorne, 2007; Menezes, 2013) sees an individual as a social being who learns language from others, getting scaffolding from them. Hence the theory seems to imply that the learner's L1 in his her social milieu plays a role in L2 learning. On the other hand, theories of second language acquisition which apparently trivialise or reject the role of the L1 in L2 learning include the Acculturation Model (Schumann, 1978) which advocates for the learner's immersion in the target language, and Krashen's Input Hypothesis which emphasises on comprehensive input in the target language (Krashen, 1985).

Similarly, language teaching methods such as the Grammar-Translation Method (Thornbury, 2000; Richards and Rodgers, 2007), Communicative Language Teaching (Larsen-Freeman, 2000), Dodson's Bilingual Method (Dodson, 1967), The New Concurrent Method (Jacobson, 1990), Community Language Teaching (Curran, 1976), all seem to either tolerate or advocate for use of the learners' L1 in the L2 classroom. However, the Direct Method (Thornbury, 2000; Richards and Rodgers, 2007), the Audio-Lingual Method (Larsen-Freeman, 2000; Richards and Rodgers, 2007), and the Natural Approach (Krashen and Terrell, 1995; Nunan and Lamb, 1996) reject the use of the L1 in L2 teaching and learning.

However, there are other views on language teaching that eschew the notion that there can be a single best method. Larsen-Freeman (2000) rejects absolutism and calls for relativism and pluralism in language teaching. Kumaravadivelu (2006) advances what he calls Postmethod pedagogy, which advocates for particularity, practicality, and possibility in what language teachers do. Gebhard and Oprandy (1999) argue that instead of being concerned with a search for the best method, the teacher should be concerned with the learner and trying to find out what works for them. Similarly, Tribble 
(1997) calls for teacher independence, avoidance of fixed ideas, exploration of fashionable formulas and principles, as well as experimenting with techniques in the classroom.

\subsection{Code-switching}

Fromkin and Rodman (1998) view code-switching as a universal language contact phenomenon reflecting the grammars of two languages working simultaneously and it occurs where there are groups of bilinguals who speak the same two languages. To Cook (2008:174) code-switching is conceptualised as 'going from one language to the other in mid-speech when both speakers know the same two languages.' Myers (2008:43) gives a language-learner-specific definition of code-switching by defining the phenomenon as 'a linguistic term usually used when learners of a second language (L2) include elements of their mother tongue in their speech.' Poplack, (cited in Kim, 2006) says code-switching is the alternate use of two languages in a single discourse, sentence or constituent. Clyne, (cited in Kim, 2006) views code-switching as occurring within a sentence or between sentences. Also, Benson (2001) defines code-switching as the use of two languages within one conversation or text and says the phenomenon is also referred to as codemixing, codeshifting, language alternation, language mixture, and language switching.

Ferguson (2003) came up with a three-fold broad categorisation of code-switching thus: codeswitching for curriculum, code-switching for management of classroom discourse, and codeswitching for interpersonal relations. Within each of these three broad categories are many narrower functions.

According to Jenkins (2009), speakers who have more than one language available to them may codeswitch or code-mix as a matter of choice, and also for other pragmatic or expressive reasons. This agrees with Das's study (2012) which shows that code-switching can be used as a strategy to fulfil certain objectives which include to minimise and emphasise differences between interlocutors, to signal language preference, to obviate difficulties caused by failure to find the correct referential terms in one language, to frame discourse, to contrast personalisation and objectification, to convey cultural-expressive messages, to dramatise words in order to attract attention, to lower language barriers between speakers and audience, and to reiterate messages.

Baker (2006) identifies the following functions of code-switching: to emphasise a point, to substitute a word in place of an unknown word in the target language, to express a concept that has no equivalent in the culture of the other language, to reinforce a request, to clarify a point, to express identity and to communicate friendship, to ease tension and to create humour, and to introduce certain topics.

\subsubsection{Code-switching in Educational Settings}

Many studies have been carried out on the subject of code-switching in educational settings and the phenomenon was found to be prevalent, though sometimes an unconscious activity. Code-switching in educational settings is viewed by Macaro (2009) as similar to the code-switching activities that occur in various real-life situations, such as the ones explored in the preceding sub-section. Macaro (2005:72) also observes that code-switching is a common phenomenon in the L2 classroom where the learners share the same mother tongue, and that code-switching by L2 teachers 'has no negative impact on the quantity of students' L2 production', but may actually increase and improve L2 production if expertly done.

(Macaro, 2005:80) also argues that 'There is nothing unnatural or 'psycholinguistically disturbing' about codeswitching in the classroom. It just mirrors a natural process happening in naturalistic discourse' 
Ferguson, (cited in Baker, 2006:295) observes that code-switching:

is not only very prevalent across a wide range of educational settings but also seems to arise naturally, perhaps inevitably, as a pragmatic response to the difficulties of teaching content in a language medium over which pupils have no control.

On what language teachers think about code-switching, Macaro (2005:68) observes that although studies seem to show that bilingual teachers believe that 'the L2 should be the predominant language of interaction in the classroom ... in none of the studies I have come across is there a majority of teachers in favour of excluding the L1 altogether.'

In a related study, Bozorgian and Fallahpour (2015) inquired into the amount and purpose of L1 use in EFL classrooms by teachers and learners at two English language institutes in Iran. The researchers found out that though there was a limited amount of L1 use, the teachers and learners did use codeswitching to enhance the language teaching and learning process. The two researchers unearthed that learners used the L1 to ask questions, answer questions, scaffolding (helping each other in group tasks and other situations), self-correction, and for seeking clarification and elaboration. Bozorgian and Fallahpour (2015:79) concluded that though the L1 was minimally used, the language teachers and learners were not reluctant to use it, and recommend that,

L1 can be used and actually should be used as an aid by the teachers to convey meaning, manage the classroom, make a friendly environment, reduce the students' anxiety, facilitate communication, elaborate on the course objectives and clarify the ambiguous points ... The students are also allowed to use their L1 for scaffolding and peer learning, but they must not use it more frequently to overshadow their L1 exposure to L2/EFL, which makes them lazy, and interferes with their L2/EFL learning. L1 should be used in a way that students L1 is an effective tool for improving and facilitating L2/ EFL learning and teaching....

Sert (2005) observes that like their teachers, learners are not always aware of the reasons for codeswitching and its functions and outcomes. Sert goes on to explain the code-switching functions that were identified by Eldridge (1996), which are equivalence, floor holding, reiteration, and conflict control. The equivalence function is whereby the learner makes use of the L1 equivalent of a lexical item in the target language, which may be done when the learner lacks the competence for using the target language explanation for the lexical item in question. In floor holding, learners fill the stopgaps with the L1, so as to avoid gaps in communication. This may be due to lack of fluency in the target language but may result in loss of target language fluency in the long term. Reiteration is a learner code-switching function in which messages are reinforced, emphasised or clarified and may be because the learner has failed to transfer meaning exactly in the target language, or may be done to show the teacher that the learner has comprehended. Finally, code-switching for conflict control is whereby the student code-switches to avoid misunderstandings (Sert, 2005).

Storch and Aldosari (2010) conducted a study on the use of the L1 (Arabic) in EFL teaching and learning and concluded that the use of the L1 by the learners seemed to serve important cognitive, social and pedagogical functions but the researchers are against the idea of learners using L1 extensively. Storch and Aldosari, however, point out that to restrict or prohibit the use of L1 in L2 classes is to deny learners the opportunity of using an important tool.

In a related study, Lee (2010) investigated the use of code-switching in ESL lessons in secondary schools in Malaysia, and found out that the majority of the teachers said code-switching should be used in the English classroom but it should be used to a limited to specific purposes, that is, the teachers advocated the maximisation of the target language. The teachers revealed that they saw the need for code-switching to help learners feel comfortable and confident, to allow weaker students to comprehend the text being used, and to aid learning. In addition, teachers agreed that code switching does promote bilingualism and it facilitates second language learning. Code-switching was also seen as a strategy for the teaching and learning process. On top of that, teachers believed that code 
switching helped students relate their first language (L1) to their second language (L2). The use of code switching in instruction helped students to clear doubts and uncertainties over a subject matter (Lee, 2010).

According to Clegg and Afitska (2011), though language practices such as code-switching are a controversial issue often condemned by authorities and not accepted by teachers in sub-Saharan Africa, code-switching has important pedagogical functions. These are explaining and elaborating on concepts, increasing participation in the classroom, establishing good relationships in the classroom, enabling the smooth running of the lesson, as well as establishing connections with the learners' local culture.

In Namibia, Simasiku (2014) investigated the perceptions of Grade 10 ESL teachers about the effects of code-switching in their classrooms and found out that the majority of the teachers viewed codeswitching as having a positive effect on learner participation and acts as a scaffold to support learners who lack proficiency in the target language. The majority of the teachers also revealed that their learners showed enthusiasm and happiness when code-switching was allowed in the classroom, while one said the learners were sad and another said the learners appeared indifferent. The teachers suggested that the learners were happy and enthusiastic when code-switching was allowed because the learners were free to express themselves in their L1, were confident they would not make mistakes, and they quickly mastered what was taught. The one teacher who said the learners' appeared sad gave the reason that the learners expected the lesson to be conducted in English but were disappointed when teachers code-switched. Simasiku's study also revealed that though teachers appreciated monolingual teaching to enhance the learners' linguistic competence in English, they saw codeswitching as tool of improving their learners' comprehension in English.

Still Namibia Simasiku, Kasanda and Smit (2015) carried out a study to find out why secondary school teachers were not using code-switching in Grade 10 English medium classrooms even in the face of the learners failing to understand what the teachers were communicating. The findings were that the teachers were hostile towards the use of code-switching, citing the language policy that insists on English only, school rules that demanded English exclusivity, lack of vocabulary in the mother tongue, misconceptions about job opportunities (the belief that is the mother tongue was used in the classroom, the learners might later fail to be employed), as well as the fear that code-switching might result in the mother tongue finding its way into the learners' writing.

In another study, Simasiku, Kasanda and Smit (2015) investigated whether code-switching enhanced learners' academic achievement in the Caprivi Education Region of Namibia at Grade 10 level of the secondary school. The study revealed that from the point of view of teachers, code-switching had the benefits of making learners understand concepts, instructions and topics, making teacher explanations easy, keeping learners actively involved in lessons and stimulating participation. However, the teachers also revealed that the majority of their learners preferred English as the medium of instruction because it is the medium through which they should learn English and is also the medium of instruction for Namibia, so that everyone can understand since the learners have different mother tongues, because English is compulsory and beneficial, and because it is school policy to use English. However, other learners preferred to use local languages for easy communication because they lacked the vocabulary of English and were incompetent in it, and because the teachers allowed the L1 to be used when learners were working in groups. The majority of the teachers also preferred their learners to use English for the following reasons: the belief that learners cannot learn English through local languages, English is the only medium of instruction or international language used world-wide which is also the official language and medium of instruction for Namibia, policy demands that English be used, for learners to practise using English and improve their communication skills, all subjects are taught in English except the local language, and that learners are tested in English.

\subsubsection{Negative Impact of Code-switching in the Classroom}

Despite the positive gains of L2-L1 code-switching reviewed in the above section, some arguments have been put forward against code-switching in L2 teaching and learning. According to Macaro 
(2005:68), 'By far the majority of bilingual teachers regard codeswitching as an unfortunate and regrettable but necessary.'

Cook (2002) observes that in instances where classroom members do not share the same L1, codeswitching may create problems as some learners will feel left out in the teaching and learning process. Since it is impossible for the teacher to relate to all the mother tongues of the learners in the classroom, code-switching should be avoided and the target language should be used consistently instead.

Another argument is advanced by Eldridge (1996:310), who asserts that if learner code-switching continues in the classroom, it may result in fossilisation and the language acquired would then become a hybrid variety, and the learners would find themselves severely linguistically deprived with target language code monolinguals.'

In addition, code-switching may be associated with the notion of negative transfer, 'the inappropriate use of the first language (L1) or dialect (D1) when speaking or writing the second language (L2) or dialect (D2)' (Siegel, 2009:48).

Furthermore, Sampson (2011) argues that if learners feel that code-switching is allowed for all communicative functions in the classroom, they may deliberately overuse the phenomenon even when they have the proper linguistic resources to express themselves in the L2.

Also, Krashen and Terrell (1995) call for L2 exclusivity in L2 learning, arguing that language learners acquire the L2 through the same natural way they learn their L1.

Furthermore, when used by L2 learners, code-switching is regarded by some teachers as off-task, deviant or disruptive behaviour and as evidence of not thinking as much as possible in the target language (Macaro, 2005).

In light of the arguments for and against code-switching in L2 teaching and learning, Macaro (2009:38) calls for optimal use of code-switching, whereby 'code-switching in broadly communicative classrooms can enhance second language acquisition and/or proficiency better than second language exclusivity.' Macaro (2005) also calls this a theory of optimality, that is, how and when code-switching leads to 'language learning, learning how to learn, and to the development of communication skills. Macaro also says to advocate total freedom to code-switch at will is not acceptable and rejects phrases such as 'use the L2 as much as possible' or 'judicious use of L1' for being not informative enough.

\subsection{Methodology}

The study employed the qualitative research designed that used the interview tool to gather data.

\subsection{Qualitative Research}

According to Matthews and Ross (2010), qualitative research seeks to find out the subjective understandings, feelings, opinions and beliefs and data are gathered in the words or expressions of the research participants themselves. Similarly, Hennink, Hutter and Bailey, (2011) state that the focus of qualitative research is on understanding behaviour, beliefs, opinions, emotions, views, processes, social interactions and meanings.

\subsection{Sample}

Two selected secondary schools, an urban boarding school and a rural day school (School A and School B respectively) as well as four ESL teachers from the schools (Teacher A, Teacher B, Teacher $\mathrm{C}$ and Teacher $\mathrm{D}$ ), were purposively sampled. This is in keeping with qualitative research.

The two secondary schools selected for this study, School A and School B, were purposively sampled on the basis of their different locations and distinct characteristics. 
School A is an urban government boarding secondary school, while School B is a rural day secondary school that is run by the Masvingo Rural District Council. I, therefore, felt that the teachers of these distinctly different secondary schools would provide useful, insights on the perceptions of ESL teachers on learners' code-switching.

Two Form Three and two Form ESL teachers were also purposively sampled on the basis of being trained teachers of English who have taught the subject for a minimum of ten years. I, therefore, felt that this sample of four teachers would provide some useful insights on the phenomenon under investigation.

\subsection{Data Collection Tool}

Data were gathered using interviews, one of the tools that are in keeping with qualitative research (Nyawaranda, 2003; Punch, 2005; Merriam, 2009; Best and Khan, 2014; Gray, 2014).

The four ESL teachers were interviewed on a one-to-one basis using the semi-structured interview guide.

\subsection{Results}

\subsection{Results from Interview with Teacher A}

In the interview with Teacher A, the teacher confirmed that her learners indeed code-switched for a variety of code-switching functions, especially when they are facing difficulties, for example to express themselves better during debates, and sometimes the learners code-switch spontaneously, but sometimes the teacher instigated the learners' code-switching when he saw that they were facing difficulties.

Teacher A showed mixed feelings about the code-switching done by her learners of English. He revealed that on the one hand he was sometimes tolerant of his learners L1 use because students are more comfortable expressing themselves in Shona, and so "it would be doing a disservice if we do not allow Shona." He added that "If you were to force students to speak in English they wouldn't learn." To further express his tolerance of code-switching by learners of English, Teacher A gave the following example: "At one school where I taught, students who spoke in Shona were supposed tohave their names written so that they would be forwarded to the headmaster for punishment but you would have a class that would be ... silent from six to six." Teacher A also showed his positive attitude learners' code switching by observing that "Not allowing students to use Shona is suppressing the child who might have a very important point to express." Apart from being tolerant of learners using their L1 during the learning of English, Teacher A showed that he even encouraged the learners to sometimes resort to their mother tongue. "Sometimes I ask them to express themselves in Shona if I see that they have difficulties."

On the other hand Teacher A revealed that he sometimes discouraged his learners from using Shona because "We normally teach for exams so normally our methods are tailor-made to suit exams so at times we encourage them to use English ... We might encourage them to use English though they can't express themselves because of Ministerial regulation ... Heads say they (learners should use English."

\subsection{Results from Interview with Teacher B}

When asked whether her English learners code-switched during English lessons, Teacher A revealed that the learners sometimes code-switched and gave the example of "when explaining vocabulary." She also said sometimes the learners code-switch spontaneously, or to use her own words, "not knowingly."

Teacher B displayed an ambivalent attitude towards her learners' code-switching. When asked if she thought her pupils should code-switch she said, "I think it's ok because children are socialised to 
speak in their first language and they have less time speaking in English." She also acknowledged that by code-switching, learners expressed themselves freely.

However, when asked how she reacts to her learners' code-switching Teacher A showed that she prefers that her learners not code-switch when she said, "I just encourage them to express themselves in English."

\subsection{Results from Interview with Teacher C}

In the interview with Teacher $\mathrm{C}$, the teacher revealed that her English class code-switched "many times" and she gave group discussions as examples of situations in which the learners code-switched.

When asked how she reacted to her learners' code-switching, Teacher $\mathrm{C}$ expressed her mixed feelings when she asserted that, "Sometimes I stop them from speaking in Shona and encourage them to use English though at times such kind of pupils will keep quiet."

\subsection{Results from Interview with Teacher D}

Teacher D revealed that her English learners code-switched when learning English and she gave the group or pair-work situation as an example of instances in which they code-switched. "Yes if I give them say some work to do in groups or in pairs aha instead of discussing in English they use their own home language."

Teacher D expressed her intolerance of her learners' code-switching, giving the reason that if learners avoid code-switching they will learn the L2 through oral practice in English, which they will then convert into writing. In her words, "I discourage them because they have to learn the second language. It is more challenging than their home language so they have to practise as much as they ... can because when they discuss they have to practise orally so that whatever they will have discussed then they will put it down in writing so there should ... be time for them to use the second language."

\subsection{Discussion}

In the interviews that I held with the four teachers of English, all of them confirmed that their learners code-switched when learning English, and that they did so when they faced difficulties in expressing themselves, when explaining vocabulary, during pair work and group work, and sometimes spontaneously. This again points to the need by the learners to be understood by their teachers as well as to understand each other.

In the interview that I held with Teacher A (urban boarding secondary school), the teacher expressed that he was sometimes tolerant of his learners' code-switching and gave the reason that he found the learners to be more comfortable expressing their views when they code-switched. He also observed that not allowing Shona in his class of English would be doing a disservice the learners or suppressing the student who would the fail to learn. The teacher revealed that sometimes he actually encouraged the learners to code-switch to their L1 when they faced difficulties in expressing themselves.

Teacher A's view seems to agree with Storch and Aldosari's (2010) study on the use of the L1 in L2 teaching and learning, in which the researchers conclude that 'the use of the L1 by the learners seems to serve important cognitive, social and pedagogical functions.'

Teacher A's perception of his learners' code-switching also seems to be informed by the Common Underlying Proficiency (CUP) model of L2 acquisition (Cummins, cited in Baker, 2006) which holds that an L2 learners' skills that have been developed in the L1 would positively transfer to the L2 and aid acquisition of literary skills in the L2 (Talebi, 2014). This model holds that 'Conceptual knowledge developed in one language helps to make input in the other language comprehensible' (Suliman, 2014:359). The L1 and the L2 are, thus, seen as existing side by side and complementing each other (Baker, 2006). Teacher A's tolerance and encouragement of his learners' L1 also seems to be in support of Additive Bilingualism, which promotes the development of both the L1 and the L2 
and encourages language users to be flexible in both languages, with the addition of the second language and culture not likely to replace or displace the L1 and culture (Baker, 2006). The L1 is not done away with as the language of instruction. Teacher A's positive perception on his learners' codeswitching also confirms McMillan and Rivers' (2011) study, in which some native-English speaker teachers of EFL at a university in Japan were of the view that students should be allowed to use their L1 in the EFL classroom to facilitate learner-learner interaction and peer assistance, to cater for students' low L2 proficiency, to build rapport through humour, and as a form of learners' L2 needs analysis.

However, Teacher A also revealed that he sometimes discouraged learners from code-switching when learning English because of examinations (which do not allow code-switching), and because of the Ministry of Education's English-only policy at secondary school level in Zimbabwe.The issue of policy also came out in Nyawaranda's (2000) study on L2 teachers' beliefs about the use of Shona in teaching English in Zimbabwe, in which one of the participating teachers believed in the use of Shona. Nyawaranda concludes that this teacher's use of Shona in English lessons is in contradiction with Zimbabwe's language policy on instruction, which states that all instruction from the third grade of the primary school (before the policy was amended in 2006 to make English the compulsory medium of instruction from the first year of secondary education) except in the teaching of local languages should be in English. This

continued use of Shona in ESL instruction, let alone its use in the teaching of other subjects, shows the complexity of choosing what language to use in the classroom. This complexity demonstrates that language use in the classroom cannot be effectively legislated by language policy (Nyawaranda, 2000:39).

The issue of policy as a reason why some teachers shun code-switching in L2 teaching, sometimes despite their beliefs in its usefulness, also came out in Simasku, Kasanda and Smit's (2015) study, in which some secondary school teachers in Namibia were hostile to code-switching, citing the country's language policy on instruction, and in turn school rules, which insist on English exclusivity.

In the case of Teacher B, (School A), while she expressed the view that it is all right for her learners of ESL to code-switch because they are socialise to speak in their L1, in which they express themselves freely, her overall stance seems to be that the learners should use English only in the English lessons, as she revealed when her learners code-switched she encouraged them to speak in English. Teacher B's stance, thus, seems to coincide with what Macaro (2001) calls the 'maximal' position on code-switching, whereby while the teacher may agree in principle that all teaching and learning should be in the target language, he or she begrudgingly concedes that in reality the L1 will be used.

By exhibiting a seemingly overall negative attitude towards her learners' use of their L1, Teacher B seems to subscribe to the Separate Underlying Proficiency (SUP) hypothesis of L2 acquisition (Cummins, cited in Baker, 2006), which sees a negative relationship between the L1 and the L2 and postulates that 'proficiency in L1 would be separate from proficiency in L2 and that language representations would be stored separately in an individual's operating system ... L1 would impede learning in L2 or delay its development ....' (Talebi, 2014:215).

Teacher B's stance also seems to fit, to some extent, into the Subtractive Bilingualism model, which demotes the L1 (Baker, 2006), and learners are moved away from their L1. The second language and culture are acquired to replace or demote the L1 language and culture (Ndamba, 2013).

Seemingly in support of Teacher B's apparently negative view of the learners' use of their L1 in L2 learning is Eldridge (1996) who observes that code-switching by L2 learners may result in the acquisition of a hybrid L2 variety and that the L2 learners will be severely linguistically deprived when communicating with target language monolinguals, Siegel (2009) also associates codeswitching with the notion of negative transfer, in which the L1 is inappropriately used when using the L2. In addition, Sampson (2011) is of the view that if code-switching is allowed for all 
communicative functions in the classroom, learners may over-use it even when they have the resources to express themselves in the L2. Teacher B also be a believer, to a greater extent, of the notion of L2 exclusivity (Krashen and Terrell, 1983), a notion whose premise is that language learners acquire the L2 through the same natural way they learn their L1 (that is, by listening to it and speaking it).

In the interview that I held with Teacher C (rural day secondary school) although she expressed a partially negative view of her learners' code-switching by stating that sometimes she stops them from speaking in Shona, she acknowledged that this tends to make the learners quite during English lessons. This observation is shared by Nguyen (2010) who suggests that if teachers are tolerant of their L2 learners' L1 use, this could encourage their participation in the ESL classroom, so the teacher's attitude to learners' L1 use should be positive so that the learners are not humiliated when they use their L1 to aid the development of the L2.

In largely tolerating her learners' use of their L1, like Teacher A, Teacher C seems to be informed by the Additive Bilingualism which promotes the development of both the L1 and L2 and encourages the users' flexibility in both (Baker, 2006), as well as by Cummins' Common Underlying Proficiency (CUP) model (Cummins, cited in Baker, 2006), whose basic premise is that when the child learns one language, he or she acquires skills and metalinguistic knowledge that can be depended on when working in another language, so the model provides the base for the development of both the L1 and the L2. In other words, according to Suliman (2014:359), 'Conceptual knowledge developed in one language helps to make in the other language comprehensible.'

Also, Teacher C's apparent tolerance seems to point to her recognition of her learners' multicompetence, which is defined as the compound state of the mind with two grammars (Cook, 2002). Cook (2012) also states that multi-competence does not see the virtue of making the learners use the L2 only, since the concept of multi-competence means that the L1 is always present in the language users' minds. Hence it would be artificial and sometimes inefficient to avoid its use. Also in support of L2 teachers' positive attitude towards L2 learners' use of their L1 is Corder (1992) who argues that L2 learners possess a language system which is potentially available to aid L2 acquisition, and the learners know something what language is for, as well as its communicative functions and potentials. In the same vein, Harbord (1992:35) argues that allowing use of the L1 in the L2 classroom is a humanistic approach which allows learners to express themselves and to be themselves, hence rigidly 'eliminating or limiting the native language does not appear to guarantee better acquisition, nor does it foster the humanistic approach that recognises learners' identities as native speakers of a valuable language that is much a part of them as their names.'

In the interview with Teacher D, she expressed that she is intolerant of her learners' switching to their L1, giving the reason that if they avoid code-switching, they will learn English through oral practice, which then convert into writing. With regard to code-switching by her learners, Teacher D, thus, seems to believe in Krashen's Input Hypothesis (Krashen, 1985), the Direct Method (Richards and Rodgers, 2007), and the Natural Approach (Krashen and Terrell, 1995), all of which advocate dispensing with the learners' L1 in L2 learning. Teacher D's view that her learners be encouraged to use English also to some extent coincides with one of the basic tenets of Communicative Language Teaching, which is that although judicious use of the learners' L1 is permitted, 'whenever possible, the target language should be used during communicative activities ... students ... realise that the target language is a vehicle for communication....' (Larsen-Freeman, 2000:132).

\subsection{Conclusion and Recommendations}

However, the teachers also expressed an awareness of the possible negative impact of code-switching in L2 teaching as is also noted by scholars such as Sert (2005), Cook (2002), as well as Moduopela (2013).

From the interviews with the four teachers it emerged that the teachers were largely tolerant of their learners' code-switching as it fostered learner understanding and made expression of ideas and 
thoughts easier. This suggests that the teachers viewed the learners' L1 as playing a positive role in L2 learning as espoused in the theory of Additive Bilingualism (Baker, 2006), and the Common Underlying Proficiency (CUP) model (Cummins, cited in Baker, 2006), and as advocated and/or unearthed by scholars such as Macaro (2005), Nguyen (2010), (Cook, 2012), Deller and Rivonlucri (2013), and Choong (2013).

However, some reservations were also expressed by the teachers about their learners' code-switching, thereby confirming the views and/or findings of authors such as Eldridge (1996), Sert (2005), Siegel (2009), Sampson (2011), as well as Simasiku, Kasanda and Smit (2015).

From the results of the study, it can thus be concluded that code-switching by ESL learners is very much alive in secondary schools in Zimbabwe and both the teachers find it to be a useful L2 learning tool, although they are also aware of the possible negative impact of the phenomenon in the L2 classroom.

\subsection{Recommendations}

In light of the findings of the study and the conclusions reached in the preceding section, therefore, I make the recommendations to language policy planners, the Ministry of Primary and Secondary Education, ESL teachers, as well as to the national examination board. A recommendation is also made for further research.

To language policy planners in Zimbabwe and other 'Outer Circle' countries, I recommend that the English-only policy in secondary education be revised, as code-switching evidently plays an important pedagogic function in the teaching of not only ESL but apparently other subjects. This is supported by Nyawaranda (2000:39), who posits that the continued use of Shona in ESL instruction, let alone its use in the teaching of other subjects, shows the complexity of choosing what language to use in the classroom. This complexity demonstrates that language use in the classroom cannot be effectively legislated by language policy.

There could also be need for a paradigm shift on the part of language policy planners in Outer Circle countries such as Zimbabwe from the current exo-normative model to the endo-normative or nativised model which would be advantageous not only to teachers by legitimising the teachers' own model thereby boosting the ESL teachers' self-confidence and self-esteem (Kirkpatrick, 2007) but also the learners who may easily identify with this model and thus find it easier to master.

To the Ministry of Primary and Secondary Education, I recommend that workshops be convened for ESL teachers so that the teachers are sensitised not only to the important role that code-switching may play in ESL teaching and learning, but also to how best this teaching and learning tool may be contextually employed without compromising the learners' mastery of the target language.

To ESL teachers, I recommend that they desist from being servants of either monolingual or bilingual teaching approaches and methods of L2 teaching and allow learners to code-switch whenever necessary.

To examination boards for countries in 'Outer Circle' countries such as the Zimbabwe School Examinations Council, I recommend, without advocating for acceptance or condoning of errors, that the examination boards be sensitive to aspects of local English varieties rather than prescribe exonormative or native speaker models which both the ESL teachers and learners would find difficult or impossible to achieve. It is my submission that the goal of L2 instruction should be communicative competence and this is supported by Brown (1987), Richards and Rodgers (2007), Hoff (2013), and Ohmaye (2013), not necessarily native speaker proficiency.

Finally, although this study has apparently gained useful insights into the use of code-switching in ESL teaching and learning in secondary schools in Zimbabwe thereby contributing to the body of knowledge on L2 pedagogy, there might be need for further research into what is obtaining at other secondary school types such as mission boarding schools and private schools. 


\section{References}

Al-Nofaie, H. (2010). 'The attitudes of teachers and students towards using Arabic in an EFL classroom in Saudi public schools: A case study.' Novistas ROYAL, 4(1), pp. 64-95.

Atkinson, D. (1987). 'The mother tongue in the classroom. A neglected resource?' English Language Teaching Journal, 41(4), pp. 241-247.

Baker, C. (2006). Foundations of bilingual education and bilingualism. Clevedon: Multilingual Matters.

Benson, E. (2001). 'The neglected value of codeswitching research in the US.' Language and Communication, 21(1), pp. 23-36.

Bozorgian, H. \& Fallahpour, S. (2015). 'Teachers' and students' amount and purpose of L1 use: English as a foreign language (EFL) classrooms in Iran.' Iranian Journal of Language Teaching Research, 3(2), pp. 67-81.

Brown, H.D. (1987). Principles of language learning and teaching. Harlow: Pearson ESL.

Brown, H.D. (2000). Principles of language learning and teaching. Harlow: Pearson ESL.

Chimhundu, H. (1997). Intergovernmental conference on language policies in Africa. Final Report. Harare: UNESCO.

Choong, K.P. (2006). Teachers' College, Columbia University Working Papers. TESOL and Applied Linguistics 6(1) pp. 1-3.

Clegg, J. \& Afitska, O. (2011). 'Teaching and learning in two languages in African classrooms.' Comparative Education, 47(1), pp. 61-77.

Constitution of Zimbabwe Amendment (No. 20) (2013). Harare: Government Printers.

Cook, V. (2001). 'Using the first language in the classroom.' Canadian Modern Language Review, 57, pp. 402-427.

Cook, V. (2002). Portraits of the L2 user. Clevedon: Multilingual Matters.

Cook, V. (2008). Second language learning and language teaching. London: Hodder and Stoughton.

Cook, V. (2012). 'Multi-competence.' Available at: homepage.ntlworld.com/Vivian.c/Writings/Papers/MCentry.htm

Corder, S.P. (1992). A role for the mother tongue. In S. Gass and L. Selinker (eds.) Language transfer in language learning. Amsterdam: John Benjamin Publishing.

Curran, C.A. (1967). Counselling learning in second language. Apple River: Apple River Press.

Das, B. (2012). 'Code-switching as a communication strategy in conversation.' Global Media Journal: Indian Edition, 3(2), pp. 1-120.

Deller, S. \& Rinvolucri, M. (2002). Using the mother tongue. London: Delta Publishing.

Dodson, C.J. (1967). Language teaching and the bilingual method. London: Pitman.

El-dali, H.M. (2012). 'L1 and second language learning: A non-stop debate.' International Journal of Academic Research in Progressive Education and Development, 1(2), pp. 8-32. 
Eldridge, J. (1996). 'Code-switching in a Turkish secondary school.' English Language Teaching Journal, 50(4), pp. 303-311.

Ferguson, G. (2003). 'Classroom code-switching in post-colonial contexts: Functions, attitudes and policies.' AILA Review, 16, pp. 38-51.

Fromkin, V. \& Rodman, R. (1998). An introduction to language. Fort Worth: Hacourt Brace College Publishers.

Gebhard, J.G. \& Oprandy, R. (1999). Language teaching awareness: A guide to exploring beliefs and practices. Cambridge: Cambridge University Press.

Gray, D.E. (2014). Doing research in the real world. Los Angeles: Sage.

Grosjean, F. (1982). Life with two languages: An introduction to bilingualism. Cambridge: Harvard University Press.

Hachipola, S.J. (2012). A survey of the minority languages in Zimbabwe. Harare: University of Zimbabwe Publications.

Hamers, J.F. \& Blanc, M.H.A. (1990). Bilinguality and bilingualism. Cambridge: Cambridge University Press.

Harbord, J. (1992). 'The use of mother tongue in the classroom.' ELT J ournal, 46(4), pp. 350-355.

Hennink, M., Hutter, I. \& Bailey, A. (2001). Qualitative research methods. London: Sage.

Hoff, M.S.T. (2013). L1 use in EFL instruction. Masters Thesis. Oslo: University of Oslo.

Jacobson, R. (1990). Allocating two languages a key feature of bilingual methodology. In R. Jacobson \& C. Faltis (eds.) Language distribution issues in bilingual schooling. Clevedon: Multilingual Matters, pp. 3-17.

Jarvis, S. \& Pavlenko, A. (2001). Crosslinguistic influence in language and cognition. New York: Routledge.

Jenkins, J. (2009). 'Points of view and blind spots: EFL and SA.' International Journal of Applied Linguistics, 16(2), pp. 137-162.

Kadenge, M. \& Mabugu, P. (2009). 'The phonological characteristics of Shona loanwords from English.’ NAWA Journal of Language and Communication, 3 (1), pp. 101-116.

Kafes, H. (2011). 'A neglected resource or an overvalued illusion: L1 use in the foreign language classroom.' International Journal on New Trends in Education and Their Implications, 2(2), pp. 128140.

Kim, E. (2006). 'Reasons and motivations for code-mixing and code-switching.' Issues in EFL, 4(1), pp. 43-61.

Krashen, S.D. \& Terrell, T.D. (1983). The Natural Approach: Language acquisition in the classroom. Hayward: The Alemany Press.

Krashen, S.D. \& Terrell, T.D. (1995). The natural approach: Language acquisition in the classroom. London: Prentice Hall Europe.

Krashen, S.D. (1985). The Input Hypothesis: Issues and implications. New York: Longman.

Kumaravadivelu, B. (2006). Understanding language teaching: From method to postmethod. Mahwah: Laurence Erlbaum Associates. 
Lantolf, J. \& Thorne, S.L. (2007). Sociocultural Theory and second language learning. In B.C Patten \& J. Williams (eds.) Theories in second language acquisition. Mahwah: Laurence Erlbaum, pp. 201224.

Larsen-Freeman, D. (2000). Techniques and principles in language teaching. Oxford: Oxford University Press.

Lee, H.L.J. (2010). 'Code switching in the teaching of English as a second language to secondary school students.' Malaysian Journal of ELT Research, 6, pp. 1-45. Available at: www.mwlta.org.my

Lightbown, P. \& Spada, N. (2006). How languages are learned. Oxford: Oxford University Press.

Mabugu, P. (2009). African Englishes: The indigenisation of English vowels by Zimbabwean Shona speakers. The Journal of Pan African Studies, 3(1), pp. 156-173.

Macaro, E. (2005). Code-switching in the L2 classroom: A communication and learning strategy. In E. Llurda (ed.) Non-native language teachers: Perceptions, challenges and contributions to the profession. New York: Springer, pp. 63-84.

Macaro, E. (2009). Teacher use of code-switching in the second language classroom. In M. Turnbull $\&$ J. Dailey-O'cain (eds.) First language use in second and foreign language learning. Clevedon: Multilingual Matters.

Macaro, E. (2014). Overview: where should we be going with classroom code-switching research? In R. Barnard \& J. McLellan (eds.) Code-switching in English-medium classes. Bristol: Multilingual Matters, pp. 10-23.

Malmkjaer, K. (1991). The linguistics encyclopaedia. London: Routledge.

Maniam, M. (2010). 'The influence of first language (L1) on English Language (L2) writing from Tamil school students: A case study from Malaysia. Language in India, 10, pp.1-209. Availabe at: languageinindia.com

Matthews, B. \& Ross, L. (2010). Research methods. New York: Pearson Longman.

Mavhunga, E.J. (2006). 'Africanising the school curriculum: A case for Zimbabwe.' Zimbabwe Journal of Educational Research, 18 (3), pp. 440-456.

McMillan, B.A. \& Rivers, D.J. (2011). 'The practice of policy: Teacher attitudes towards "Englishonly".' System, 39, pp. 251-263.

Menezes, V. (2013). 'Second Language Acquisition: Reconciling theories.' Open Journal of Applied Sciences, 3, pp. 404-412.

Merriam, S.B. (2009). Qualitative research: A guide to design and implementation. San Fransisco: Jossey-Bass.

Miles, R. (2004). 'Evaluating the use of L1 in the English Language classroom.' School of Humanities, Centre for English Language Studies, Department of English, University of Birmingham.

Moduopela, O.R. (2013). 'Code-switching as a teaching strategy: Implications for English Language teaching and learning in a multilingual society.' IOSR Journal of Humanities and Social Sciences, 14(2), pp. 92-94.

Myers, M.J. (2008). 'Code-switching in content learning.' Realising Content and Language Learning in Higher Education, pp. 43-48. 
Ndamba, G.T. (2013). A critical review of Language-in-Education for Africa: A case of Zimbabwe. Doctoral Thesis. Pretoria: UNISA.

Nguyen, M.H. (2010). 'Encouraging reluctant ESL/EFL learners to speak in the classroom.' The Internet TESL Journal, XVI(3). Available at: http:iteslj.org/Techniques/NguyenReluctantSpeakers.html

Nunan, D. \& Lamb, C. (1996). The self-direct teacher: Managing the learning process. Cambridge: Cambridge University Press.

Nunan, D. (2000). Language teaching methodology. Cambridge: Cambridge University Press.

Nyawaranda, V. (2000). 'The use of mother tongue (Shona, L1) in second language (English, L2) instruction and learning in Zimbabwe: A case of common underlying hypothesis.' Zimbabwe Journal of Educational Research, 12 (1).

Nyawaranda, V. (2003). 'Doing qualitative research.' Zimbabwe Bulletin of Teacher Education, 12 (1), pp. 1-3.

Nziramasanga, C. (1999). Report of the Presidential Commission of Inquiry into Education and Training. Harare: Government of Zimbabwe.

Odlin, T. (1993). Language transfer. Cross-linguistic influence in language learning. Cambridge: Cambridge University Press.

Ohmaye, E. (2013). Simulation-based language learning: An architecture and multi-media learning tool. In R.C. Schank (Ed.) Inside multi-media case-based instruction. Mahwah: Lawrence Erlbaum Associates, pp. 1-101.

Peresuh, M. \& Masuku, J. (2002). 'The role of the bilingual in the bilingual-bicultural education in Zimbabwe.' Zambezia, XXIX (1), pp. 27-37.

Piasecka, K. (1988). The bilingual teacher in the ESL classroom. In S. Nicholls \& E. HoadleyMaidment (eds.) Current issues in teaching English as a second language to adults. London: Edward Arnold.

Prabhu, N.S. (1990). 'There is no best methodology - why?' TESOL Quarterly, 24(2). Available at: eric.ed.gov/?id=EJ416668

Punch, K.F. (2005). Introduction to social research. Los Angeles: Sage.

Richards, J.C. \& Rodgers, T. (2007). Approaches and methods in language teaching. Cambridge: Cambridge University Press.

Sampson, A. (2011). 'Learner code-switching versus English only.' ELT Journal, 66(3). Available at: elt.oxfordjournals.org/.../11.../elt.ccr067

Schumann, J. (1986). The pidginisation process: A model for Second Language Acquisition. Rowley: Newbury Publishers.

Sert, O. (2005). 'The functions of code-switching in ELT classrooms.' The Internet TESL Journal, IX(8). Available at: http://iteslj.org/Articles/Sert-CodeSwitching.html

Sharma, K. (2006). 'Mother tongue use in English classroom.' Journal of NELTA, 11(1-2), pp. 80-87.

Siegel, J. (2009). Keeping creoles and dialects out of the classroom: Is it justified? In S.J. Nero (ed.) Dialects, Englishes, creoles and education. ESL and applied linguistics series, New York: Routledge, Francis Taylor Group, pp. 39-70. 
Simasiku, L. (2014). The perceptions of Grade 10 English Second Language teachers about the effects of code switching in their classrooms in the Caprivi Education Region. PhD Thesis. Windhoek: UNAM.

Simasiku, L., Kasanda, C. \& Smit, T. (2015). 'Barriers to code switching in English second language medium classrooms.' International Journal of English Literature and Culture, 8(2), pp. 7-13.

Simasiku, L., Kasanda, C. \& Smit, T. (2015). 'Can code switching enhance learners' academic achievement?’ English Language Teaching, 8(2), pp. 70-77.

Simensen, A.M. (2007). Teaching a foreign language: Principles and procedures. Bergen: Fagbokforlaget.

Sridhar, S.N. (1994). 'A reality check for SLA theories.' TESOL Quarterly, 28 (4), pp. 800-805.

Storch, N. \& Aldosari, A. (2010). 'Learners' use of first language (Arabic) in pair work in an EFL class.' Language Teaching Research,14, pp. 355-375.

Storch, N. \& Wigglesworth, G. (2003). 'Is there a role for the use of the L1 in an L2 setting?' TESOL Quarterly, 37(4), pp. 760-770.

Talebi, S.H. (2014). 'Cross-linguistic transfer among Iranian learners of English as a foreign language.' Issues in Educational Research, 24(2), pp. 212-227.

Tribble, C. (1997). Writing: Language teaching: A scheme for teachers. Oxford: Oxford University Press. 